\title{
TEACHER TRAINING AT CHEMISTRY FACULTIES - MUTUAL BENEFITS? A CASE STUDY BASED ON THE EXAMPLE OF THE IRRESISTIBLE PROJECT ${ }^{1}$
}

\author{
Iwona Maciejowska \\ Jagiellonian University in Krakow, Poland \\ Jan Apotheker \\ University of Groningen, the Netherlands
}

\begin{abstract}
The training of teachers at educational science faculties prepares them better to deal with class management, individualization of teaching, evaluating, problems with motivation, etc. Teachers educated at chemistry faculties have a profound and well-established knowledge in the field of chemistry, but they demonstrate limited pedagogical skills.

Recently, the collaboration between chemists, researchers in chemistry education and chemistry teachers has become more intense. In 2013, the Jagiellonian University joined the 7th Framework Programme project - IRRESISTIBLE (http://www.irresistible-project.eu). The goal of the project IRRESISTIBLE is to design activities that foster the involvement of students and the public in the process of Responsible Research and Innovation (RRI).

A case study based on the example of the IRRESISTIBLE project is presented. Some interesting results are discussed.
\end{abstract}

Key words: educational science, science education, teacher education.

\section{Introduction}

As shown by numerous studies, both the reports prepared directly as commissioned by the European Commission (SITEP, 2011), as well as those carried out under various projects, including EC2E2N (WP12 Final Report, 2012), teacher training in Europe is highly diverse. The differences relate to such basic issues as the placement of teacher training at the faculties of pedagogy or science, and thus the title gained by the graduates. In the academic year 1917/1918, the Council of the Faculty of Philosophy of the Jagiellonian University, for the very first time after the liberation of the country, organized classes of teaching mathematics and natural sciences in secondary schools. In 1972, after numerous changes, the task of training chemistry teachers was taken over by the newly established Chemistry Teaching Methods Department (nowadays Department of Chemical Education), which is a unit of the Faculty of Chemistry, with the cooperation of the Teachers' Training Centre - a central University unit.

Both solutions have their pros and cons. The training of teachers at educational science faculties prepares them better to deal with class management, individualization of teaching, evaluating, problems with motivation, etc. However, limited contact with a chemical laboratory and superficial knowledge of chemistry (concurrent model of teacher training) often leads to the emergence of students' scientific misconceptions (Sheehan et

1 This work has been presented in the framework of 45th World Chemistry Congress (IUPAC-2015) 
al., 2011). Teachers educated at chemistry faculties have a profound and well-established knowledge in the field of chemistry, but they demonstrate limited pedagogical skills. Anecdotally, it is said that a chemist knows chemistry, but s/he is not able to teach it, while a teacher makes mistakes in chemistry, but s/he can teach them (the mistakes) well. Which solution is the best for a student? The answer usually depends on the field of study represented.

The cooperation of universities with schools usually lies now (at least in Poland) with the departments of chemical education. It is not as trivial as it might seem. The most often neglected element is the two-sidedness of the contact and partner relationships, instead of the typical, slightly patronizing attitude of one of them. One of the working groups of the European Chemistry Thematic Network Association (ECTN), operating under the guidance of Professor Ingo Eilks from the University of Bremen, has published a position paper. It is clearly stated that the parties of the cooperation usually have different objectives and expectations. "For the higher education institutions one of the probable motivations is to attract future students and to motivate pupils to choose a career in chemistry or science. But also an interest of the higher education institution can be to promote chemistry and science learning in schools to have better trained entrants in their future courses. (...) It also requires training teachers, who are then able to display the relevance of chemistry to their students. Last, but not least, the promotion of the image of chemistry (within a particular region, university, or in general) can be an objective of the higher education institutions. (...) The interests of schools and teachers are often more immediate. In most cases, teachers are looking for help in everyday practice. This can be achieved through material support (e.g. in experimentation), the dissemination of teaching materials or information, or help in the school's waste management. It can be training how to, e.g., implement experiments into the classroom without danger, fear, or from a weak knowledge base. (...) But teachers are also looking for help in displaying aspects of chemistry which cannot be shown authentically in schools. Here site visits, visits of experts to schools, or laboratory courses in universities are welcome" (Eilks et al., 2004). They also developed both a set of examples of good practice in this area, as well as a number of recommendations, which include:

- Make the link personal, reliable, and cooperative

- Make the link acknowledged, networked, and supported

- Make the link visible

- Make the link attractive and helpful for the students

- Make the link feasible to and helpful for teachers' everyday practice

- Make the link of benefit to university staff members

- Make the link structured and implement feedback and evaluation (Eilks et al., 2004)

It also happens that with the modern trend of creating various rankings, teacher education and the development of chemistry teaching departments at chemistry faculties is treated there like the proverbial fifth wheel on the wagon. Just compare the chemistry education journal impact factor, such as for example the Journal of Chemistry Education IF $=1.0$ and the one of an average 'pure chemistry' journal, for example the Journal of Organic Chemistry IF=4.7 while a review (e.g. Chemical Reviews) achieves IF $=46.5$. Therefore, can the preparation of students to work in the teaching profession and more extensive cooperation with teachers and schools deliver the benefits for both teachers and chemistry faculties? 


\section{Project IRRESISTIBLE}

Recently, the collaboration between chemists, researchers in chemistry education and chemistry teachers has become more intense. In 2013, the Jagiellonian University joined the 7th Framework Programme project - IRRESISTIBLE (http://www.irresistibleproject.eu). The goal of the project IRRESISTIBLE is to design activities that foster the involvement of students and the public in the process of Responsible Research and Innovation (RRI). To raise the awareness on RRI the project aims to increase students content knowledge about research by bringing cutting edge research into the program, and to foster the discussion among students about RRI issues by the introduction of relevant topics. By using formal (school) and informal (science centre, museum or festival) teaching we familiarize schoolchildren with science. In RRI six key issues can be formulated, which include:

- Engagement: joint participation of researchers, industry and civil society in the research and innovation process

- Gender equality: unlocking the full potential of society

- Science education: creative education to foster the future needs of society

- Ethics: Including societal relevance and acceptability of research and innovation outcomes

- Open access: free, online access to the results of publicly funded research

- Governance: the responsibility of policy makers to develop harmonious models for RRI

As part of that project, a so-called Community of Learners (CoL) was established, which aims to develop lesson plans and teaching materials to bring school students closer to the concept of responsible research and innovation in the context of recent scientific developments (cutting edge science).

According to Fazlagić, the Community of Learners may be defined as "a group of people who share the same values and beliefs, and who are actively involved in learning from each other. In such way an environment is created, in which individual team members actively and deliberately construct their knowledge together. Members - while maintaining their independence, mutual respect and cohesion of the group - are mutually supportive and cooperate with each other. The team supports all the members of the group, regardless of their functions, level of knowledge and experience. In comfort and the sense of security, the members may ask questions and make mistakes. Only in such circumstances may individual members be seen as allies. It all motivates members to stay in the group and promotes the growth of their commitment and interest, as well as ensuring progress in academic achievements' (Fazlagić, 2004). According to Wikipedia "A learning community is a group of people who share common academic goals and attitudes, who meet semiregularly to collaborate on classwork. Such communities have become the template for a cohort-based, interdisciplinary approach to higher education. This may be based on an advanced kind of educational or 'pedagogical' design." (https://en.wikipedia.org/wiki/ Learning_community).

The IRRESISTIBLE Community is composed of teachers, researchers and educators, as well as a museum representative (Figure 1). 


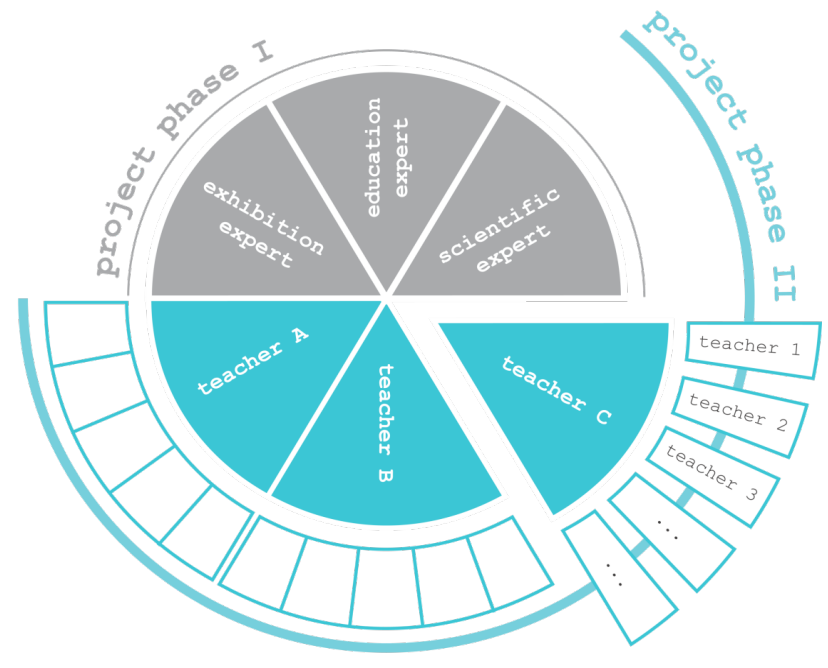

Figure 1: Composition if IRRESISTIBLE Community of Learners (IRRESISTIBLE home page).

Academics in a CoL have a number of tasks to complete. These include, for example:

- Sharing knowledge and the results of the research conducted,

- Suggesting activities (experiments, discussions, lectures) for the module designed, entitled Catalysis to Environmental Protection

- Enabling school students to carry out research using modern equipment,

- Demonstrating and discussing with students the organization of the work of research teams.

\section{A Survey}

The first CoL formation was operating from April 2014 until July 2015. Each month, a meeting of all CoL members was held. Qualitative methods were used in the research. In order to get the opinions on the classes - e.g. their suitability for the knowledge, skills and needs of the participants, the method of organization, the methods of work and proposed topics - the first five meetings ended up with completing an evaluation questionnaire by three scientists, eight teachers, four researchers in chemistry education and one museum curator. The questionnaire was prepared based on the PMI (Q) evaluation tool - Plus, Minus, Interesting (Questions), developed by Edward de Bono (PMI), except that there were some expressions added to the original questions: difficult/easy, known/unknown. Moreover, the evaluation sheet also included certain statements to be completed: I would like to know more about (explain)...., My suggestions (of changes, improvements, additions) are as follows...) The results of the study has been published this year in Polish language (Maciejowska, Krzeczkowska, 2015).

After the first year of the CoL operation, a survey was supported by semi-structured interviews, the results of which showed how the joint work is perceived by the academics of the Faculty of Chemistry (scientists who also teach university students). 
The respondents' scheme was as follows:

- A1-Associate Professor, 25 years of experience in academic work/university teaching;

- A2 -Associate Professor, 10 years;

- A3 -Full Professor, 28 years.

The following preliminary questions were prepared, which then led to the topics' development:

1. How had you imagined your role and responsibilities in the project before the meetings began?

2. After the year-long work of CoL1 - in your opinion, what was your role about in fact?

3. What are your impressions of working with teachers?

4. What surprised you?

5. What were the limitations of that cooperation? What were the difficulties?

6. Did you learn - and what did you learn - from cooperating with them?

In the responses a number of typical elements had been highlighted and then grouped by common features in four categories. According to the results of the interviews - the scientists had no prior significant contact with schools, and the contact was limited to that through their own children (A1, A3), upper secondary school graduates beginning their studies at JU (A1, A2), occasional lectures/workshops for teachers (A1, A3) or students (A1, A3), family talks (A3).

\section{Survey Results}

Written questionnaires indicate that:

- Scientists found it an interesting opportunity to get to know the knowledge and views of teachers on nanomaterials and nanotechnology; they expressed a desire to find out even more details on this subject.

- What was new to them was: some teaching methods e.g. the mind map, students' inquiry experiments, the concepts of IBSE and 6E (engage, explore, explain, elaborate, exchange, evaluate), and the issue of organizing interactive exhibitions

- It was difficult for the chemists to plan interactive activities for the Community of Learners' meeting.

Based on the interviews, it was found out that when dealing with school teachers:

1. University teachers can get to know more deeply the methodology of chemistry teaching (further training for university teachers in the field of school subjects teaching is not included in the training on that level), for example:

- Some lecturers realized how important it is to adapt the language and content of the message to the recipient...

„It is a different world, every time you need to think about what and how you want to convey, whether you are you sure that the message will get to the other person (a teacher or a student) and it will be understood „(A2)

„Students are the same everywhere - if there is something that makes them interested, they will be encouraged [to learn], but even if there is something interesting (from the perspective of a scientist) but not "sold" well, students will not be interested. It is not enough to have an interesting and useful topic; we need to have it "well-packaged". ", (A2). 
- The participation in workshops with teachers was inspiring in terms of teaching methods...

"I can see that the active methods have their advantages and I will try to use them during my classes" (A1)

„RRI or that $\mathbf{6 E}$ rule are very general things, and they fit everywhere, no matter what level of education you deal with." (A3)

„Young people have changed a lot; I still remember what our chemistry clubs looked like (...) we did not work as a team at all, (...) and I really like that [students' group work], as well as focusing on [student] projects, which, incidentally, are also missing when studying at universities, (...) and they should be the basis of learning, because then when we construct research teams they need to be interdisciplinary; people must cooperate." (A3).

2. Scientists acquired new knowledge about schools, which will be possible to be used in university education.

„,When implementing the project, we talked much about the chemistry curriculum in schools (...) now we will have the graduates who had a different curriculum [than the previous ones] followed; I learned more about what they [students - upper secondary school graduates] know and what they don't know; I need to take that into account when doing my course [for $1^{\text {st }}$ year university students] ,, (A1).

3. The scientists have gained new insights into the cooperation with the external environment, including schools

- $\quad$,Meetings with students also made me realize how we, as the scientific community, are isolated from the society. They pass on what they heard somewhere from older mates or parents, and that [the image of a scientist] was surprising. ,I wish that contact [with schools] was better in the future, because it seems to me that there are two separate worlds - "school" and "university" - and a "band gap" between the two levels. If we managed to combine the two, it would be for the benefit of everyone." (A3)

- Scientists realized how much their expertise may be helpful for secondary school teachers (usually in-service training is organised by teacher educators and not a scientist):

„I realized that the interaction with teachers is significant; they asked a whole bunch of questions, both formal and informal ones, and it reached its apogee when we met in [research] labs with their students' (A3)

"Teachers were saying many times that they needed from us sometimes some very specific knowledge, for example, we say "active sites", but to make it clear to them what an active site is... To make them able to tell young people, whether it is a single atom or a group of atoms?" (A2).

4. The subjects of the meetings affected the scientific activity of the university teachers.

„As a result of the CoL monthly meetings (...) when I do research now, I think about RRI; we incorporate it into our discussions in the research team" (A2). 


\section{Conclusions}

It is known that on the one hand, the preparation of future teachers at the Faculty of Chemistry attracts students who, in addition to obtaining a master's degree in chemistry, also become entitled to teach chemistry at school, and thus they increase their chances of getting a job; on the other hand, such a system guarantees extensive qualifications of future teachers (which then results e.g. in the students' victories in international chemistry contests and, above all, in fewer factual errors in the classroom).

What the study has demonstrated is the fact that also researchers - university teachers may benefit a lot from their contact with school teachers: knowledge in the field of teaching, knowledge about the school and its graduates, etc. They become more aware of the external environment. This is consistent with Eilks' group position paper which stated that "A co-operative and interactive link may allow university staff to learn about the chemistry taught in schools and about the learners in schools. This may help them to understand better the students entering university. It may help to attune introductory university courses by having a better insight into the curriculum and practice of science teaching at schools. (...) This also may offer the opportunity for insights into new trends and concepts in education which may influence the quality of university science education. In many cases, schools are nearer to new teaching methods and developed concepts" (Eilks et al., 2004).

\section{Acknowledgement}

This project has received funding from the European Union's Seventh Framework Programme for research, technological development and demonstration under grant agreement no 612367. It is a coordination and support action under FP7-SCIENCE-INSOCIETY-2013-1, ACTIVITY 5.2.2 Young people and science: Topic SiS.2013.2.2.1-1 Raising youth awareness for Responsible Research and Innovation through Inquiry Based Science Education. This project is co-funded by Polish Ministry of Science and Higher Education, W16/7.PR/2015.

\section{References}

Eilk, I., Ashmore, A., Avitabile, G., Barr, D., Begitt, K., Childs, P. E., Devisscher, M., Floriano, M. A., Fröhlich, J., Jones, A. M., Krzeczkowska, M., Leach, J., Mutafchieva, K., Priksane, A., Ricart, J. M., Rivail, J. L, Soevegjarto-Wigbers, D., Zahariev, A. (2004). Links with Schools - A position paper. European Chemistry Thematic Network Newsletter, 5 (5).

Fazlagić, A. (2004). Wspólnoty praktyków. Manager, 8, 4-8.

IRRESISTIBLE project. (2015). Retrieved from: http://www.irresistible-project.eu/index.php/ en/ (access 2015-08-04).

Maciejowska, I., Krzeczkowska, M., Apotheker, J., Blonder, R., Rosenfeld, S. (2015). Zespół Osób Uczących się jako propozycja rozwoju kompetencji nauczycieli i podnoszenia jakości pracy szkoły [Community of learners as a proposal of teachers' competences development and school work quality improvement. In: R.M. Janiuk (Ed.). Z chemia ku przyszłości / With chemistry into the future. Lublin, 161-173.

PMI (plus, minus, interesting) retrospective, WhatIs.com (2015). Retrieved from: http://whatis. techtarget.com/definition/PMI-plus-minus-interesting-retrospective (access 2015-0804). 
Sheehan, M., Childs, P., E., Hayes, S. (2011). Pre-service Irish science teachers' misconceptions of chemistry. Retrieved from: https://www.academia.edu/2000097/ PRE-SERVICE_IRISH_SCIENCE_TEACHERSMISCONCEPTIONS_OF_ CHEMISTRY (access 2015-08-25).

SITEP - Survey on Initial Teacher Education Programmes in Mathematics and Science (2011). EACEA - Education, Audiovisual and Culture Executive Agency. Retrieved from: http:// eacea.ec.europa.eu/education/eurydice/SITEP.php (accessed 08.04.2015).

WP12 Final Report - Towards European Quality Labels for Teacher Education Programmes, Teacher Education in Europe (2012). EC2E2N NewsLetter, 13. Retrieved from: http:// www.ec2e2n.eu/1/wp12 (accessed 08.04.2015).

Received 07 August 2015; accepted 25 August 2015

\section{Iwona Maciejowska}

PhD, Vice Chair DivCEd EuCheMS, Faculty of Chemistry, Jagiellonian University, 3 Ingardena, 30060 Krakow, Poland.

E-mail: maciejow@chemia.uj.edu.pl

Website: http://www.chemia.uj.edu.pl/maciejow/

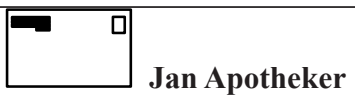

PhD., Professor, University of Groningen, Kamer 422, Nijenborgh 9, 9747 AG Groningen, the Netherlands.

E-mail: j.h.apotheker@rug.nl 